Envisioning Possibility:

Schooling and Student Agency in Children's and Young Adult Literature

\author{
John Kornfeld \\ Associate Professor \\ Sonoma State University \\ Laurie Prothro \\ Librarian \\ Harmony Union School District
}

Address correspondence to:

John Kornfeld

School of Education

Sonoma State University

1801 East Cotati Ave.

Rohnert Park, CA 94928

email: john.kornfeld@sonoma.edu

tel: 707-664-4208

fax: 707-664-2483 


\title{
Envisioning Possibility:
}

Schooling and Student Agency in Children's and Young Adult Literature

\begin{abstract}
This article provides a rationale for using literature in the classroom to explore conceptions of curriculum and teaching. We discuss a number of exemplars from children's and young adult fiction, both mainstream and less well known; offer a taxonomy for categorizing the range of visions of curriculum and teaching in the literature; and describe the responses of a group of middle school students to a unit that examined schooling in literature. We argue that reading literature which addresses student experiences in school can help students make sense of those experiences and, more importantly, open their minds to ideas about teaching and schooling that they otherwise might never have considered.
\end{abstract}

Key Words

Critical pedagogy and children's and YA literature

Schooling in children's and YA literature

Curriculum and children's and YA literature 


\section{Envisioning Possibility:}

Schooling and Student Agency in Children's and Young Adult Literature

\section{Introduction}

In the fifth Harry Potter book (Rowling, 2003), Harry and his friends, profoundly dissatisfied with their Defense Against the Dark Arts teacher, resolve to take their schooling into their own hands. The curriculum for this course, Hermione declares, should be "about preparing ourselves...for what's waiting out there. It's about making sure we really can defend ourselves.... We've gone past the stage where we can just learn things out of books. We need a teacher, a proper teacher who can show us how to use the spells and correct us if we're going wrong" (Rowling, 2003, pp. 325-326). In Harry Potter and the Order of the Phoenix, students grapple with the questions, For what should schools be preparing their students? How should learning experiences be organized? Who should decide what will be taught? And what should be the role of the teacher? In developing their own curriculum and choosing the teacher for what they call "Dumbledore's Army," they come up with their own answers to these questions.

J.K. Rowling is but one of many children's and young adult authors whose books raise these kinds of questions while offering provocative and compelling images of curriculum and teaching. Yet too often, such images are all but ignored in schools themselves. In the classroom, students generally are expected to adapt uncritically to the personality and demands of the teacher in the room; rarely are they given the opportunity to examine or to develop their own conceptions of the curriculum, the teacher's role, and their own positionality in their formal education. In fact, addressing such issues should be a key concern of curricula at all levels of schooling. The unprecedented popularity of the Harry Potter books, and their ubiquity in schools, provides the perfect stimulus for discussion in the classroom; it also provides the perfect springboard for teachers and students to read and analyze many other perspectives on curriculum and schooling that can be found throughout children's and young adult literature.

In this paper we present a rationale for using literature in the classroom to explore conceptions of curriculum and teaching, and we examine a number of exemplars from children's and young adult fiction-both mainstream and less well known — that provide a range of visions of what is and what could be. Finally, we look at the responses of a 
group of middle school students to these varied images. Most young people in the United States spend much of their lives in schools, thinking about school, or talking to one another about school; reading literature, we found, can help them not only make sense of that experience, but, even more importantly, open their minds to ideas about teaching and schooling that they otherwise might never have considered. Children's and young adult literature can reveal possibilities to readers by offering images of alternative educational experiences, or a way out of unhappy or oppressive school situations, or teachers who act as role models to young people facing the challenges of living in an often unfair world while becoming well-informed, contributing members of society. As Nilsen and Donelson (1993, p. 3) write, "Books are one of the items that the community provides to young people in the hope of helping them succeed in their journey into adulthood."

\section{Schooling, Power Relations, and Literature}

School, like children's and young adult literature, should be a realm of possibility - a place in which teachers and students together examine their lived experience and envision ways to enhance their lives and sense of efficacy in the world around them. But a description of an "ordinary" classroom usually evokes far less exciting imagery:

Learning is serious and life is hard. There is homework.... School [is] business: in Beverly Cleary's novel, Ramona the Brave (1975, p. 68), Beezus, Ramona's sister says of the teacher, “There wasn't anything really wrong with [Mrs. Griggs], I guess... she just wasn't very exciting is all. She wasn't mean or anything like that. We just seemed to go along doing our work, and that was it." But, yes, I believe that there is, indeed, something wrong with Mrs. Griggs, something very wrong with the system in which she worked. Education ought not to be just "going along doing our work, and that was it." Education should not, in fact, be so...well, so mundane. (Block, 1997, p. 17)

While mundane is far from desirable, it is not uncommon to encounter teachers even more unpleasant than Mrs. Griggs: those wary of unconventionality, like Anastasia Krupnik's teacher (Lowry, 1979) who graded her poem an F because it did not rhyme; or obsessed with control, like Mr. Chappell, Dicey Tillerman's verbally abusive English 
teacher (Voigt, 1982); or those simply weighed down by what Rowling (2003) calls the "high inquisitors" of the school bureaucracy. As the nationwide preoccupation with school accountability continues to grow, increasing numbers of teachers feel compelled to restrict classroom interaction to the inculcation of state-mandated information and knowledge in pre-approved areas of study. Pressured to provide what Hirsch (1996) refers to as "intellectual capital," too many teachers emulate Mr. Gradgrind, the nononsense teacher in Dickens's Hard Times:

Now, what I want is facts. Teach these boys and girls nothing but the facts. Facts alone are wanted in life. Plant nothing else, and root out everything else. You can only form the minds of reasoning animals upon facts; nothing else will ever be of any service to them. This is the principle on which I bring up my own children, and this is the principle on which I bring up these children. Stick to the facts, sir! (quoted in Kliebard, 1992, p. 26)

This banking concept of education (Freire, 1990) fails to acknowledge the complexity of students' and teachers' daily experiences and the contested nature of the knowledge produced in schools. Some students refuse to passively acquire the intellectual capital that Hirsch argues they need, but which they do not consider meaningful or relevant to their lives: as Kohl (1995) and many others have pointed out, life in schools often involves a struggle for control of the knowledge that is produced there. In his study of "Harold Spencer" Junior High, Everhart (1983) differentiates between two types of knowledge production: reified and regenerative. Whereas reified knowledge was the non-negotiable information, transmitted by teachers and anointed by the textbooks, that made up the formal curriculum at Spencer, regenerative knowledgetentative, arguable, and open to interpretation-was the knowledge students produced among themselves as a means of resistance to reified knowledge. Like the students at Spencer, Nick Allen in Frindle (Clements, 1996) considers it his calling to literally create knowledge in school-by inventing and defining a word, over the strong objections of his teacher, which the whole community will use:

Was Nick a troublemaker? Hard to say. One thing's for sure: Nick Allen had plenty of ideas, and he knew what to do with them. (Clements, 1996, p. 1) 
Interestingly, though, as Britzman (1986) notes, students mistakenly regard their resistance as simply a power struggle between them and an autonomous teacher; they fail to recognize the teacher's subordinate position in the top-down curriculum development hierarchy. Nor, for that matter, do students always recognize the impact on schooling of the complex interactions among various constituencies (students, parents, teachers, administrators, politicians, etc .). All parties, in varying degrees, play a role in students' knowledge and experiences in school. As Giroux and McLaren (1986, p. 215) write, "schooling represents both a struggle for meaning and a struggle over power relations."

Schools need to provide opportunities for students to understand and address these struggles. Examining schooling, the one institution in this country about which every student has knowledge, experience, and strong opinions, can help students develop what Bigelow calls a "basic skill": critical reflection on issues of equity, social justice, knowledge construction, and students' lives. Bigelow, whose high school students study the history and sociology of schooling, writes:

We need to equip students to enter society as subjects, as individuals who look around at the social architecture and ask why it is like this; who benefits and who suffers; and what will it take to make it better for everyone? Studying an institution with which they're intimately familiar seems a good place to start. (Bigelow, 1999, p. 256, emphasis in original) In Bigelow's class, studying power relations in schools promotes new levels of understanding between and among students. Moreover, this examination of the power struggles in the classroom should not be limited to student-student relations. By examining the complexities of their relationships with one another and their respective relationships to school knowledge, students and teachers can begin to ameliorate the power struggles that so often poison these relationships. Freire (1990, p. 59) advocates that education "begin with the solution of the teacher-student contradiction, by reconciling the poles of the contradiction so that both are simultaneously teachers and students." We must, as Apple (1996, p. 33) advocates, "base a curriculum on a recognition of those differences that empower and depower our students in identifiable ways." In order to understand these power relations in school, students need the opportunity to examine the institution of schooling itself and their relationship to it. 
Children's and young adult fiction can provide such an opportunity. Gough (1998, p. 93) writes that fiction "is useful to us as a means of posing options and alternatives and for connecting 'present reality' with past and/or future possibilities." Classic as well as contemporary fiction depicts various permutations of the "present reality" of schooling: the double standard that a high achiever uncovers when she refuses to perform dissections in Standing Up to Mr. O (Mills, 1998); the silencing of the students in Speak (Anderson, 1999, p. 56) by the history teacher who tells his students, "I decide who talks in here"; or the freedom of movement that a caring teacher provides a girl with Tourette Syndrome in Quit It (Byalick, 2002).

These literary embodiments of their own academic experiences help students realize that their experiences are not unique, and help students make sense of their abstract concerns and criticisms of schooling by anchoring them in something more tangible. Like Sartre, who says that "Raskolnikov's waiting is my waiting, which I lend him" (quoted in Greene, 1975), students lend part of themselves to the stories as they read them: they become a part of the world of the characters in the books, but their perceptions of that world are colored by their own experiences in school. And they emerge from the fictional worlds with a better understanding of their own. As with Pinar's (1976, p. vii) currere (a strategy using autobiographical reflection to help students make meaning of their experience), exploring schooling through literature helps students to disclose their "existential experience of external structures."

\section{Literature and Visions of Possibility}

It is vital, though, not to focus entirely on fiction that merely depicts and confirms students' traditional conceptions of schooling. To do so, especially without critiquing such images in the books students read, would only serve to reify conventional notions of mundane or repressive schooling and establish that these conceptions are, now and always, the way things are and must be. Heilman (2003) notes that according to Sutherland (1985), children's literature reflects either the politics of assent (which affirms societal norms), of attack, or of advocacy. The image of schooling in most classical literature (and, arguably, the earlier Harry Potter books as well) is grounded in the politics of assent and could potentially exacerbate rather than ease students' sense of helplessness. On the other hand, much contemporary young adult literature (such as 
Avi's Nothing But the Truth [1993]) attacks traditional structures of schooling, with characters suffering from and/or resisting the will of teachers or administration.

While such literature might encourage critique and resistance, it may not stimulate alternative conceptions of schooling. Goodman (1992, p. 168) writes that the language of critique can be helpful in raising consciousness of inequity and oppression; but it can also cultivate

a "discourse of despair" by promoting the view that people with a critical consciousness are basically unable to exert a meaningful impact within our society: that is, it [accentuates] the way schools act as agencies for social reproduction by teaching young people and their teachers to be passive in their response to a curriculum and organizational structure that serve those who dominate.

To progress beyond the language of critique, students need the opportunity to explore the works of literature that go beyond the politics of attack and into the realm of possibility. A language of possibility, Giroux (1988, pp. 135-136) writes, "would infuse pedagogical work ... with a discourse that can function so as to raise real hopes, forge democratic alliances, and point to new forms of social life." Many works of literature invite this type of discourse by offering alternatives to the traditional curriculum, depicting students involved in generative intellectual engagements in a variety of school settings. The situations differ from book to book and school to school. In Surviving the Applewhites (Tolan, 2002), a family runs the so-called "Creative Academy" established on the assumption that "education is an adventurous quest for the meaning of life, involving an ability to think things through" (p. 27); in Skellig (Almond, 1998), the unusual girl next door is home-schooled, explaining, "the mind needs to be opened out into the world, not shuttered down inside a gloomy classroom" (p. 49); and the 1954 Newbery Medal winner The Wheel on the School (DeJong, 1954) shows how students' pursuits of their own questions can change their world in wonderful and unpredictable ways.

In The Wheel on the School, the teacher establishes the space and makes the time for students to initiate and carry out their own inquiries. As he tells his initially skeptical students, "Sometimes when we wonder we can make things begin to happen" (DeJong, 1954, p. 6). Indeed, the image of the teacher as catalyst for transformative experiences in school is key to many visions of curricular possibility in children's and young adult 
literature. In some cases, the teacher simply makes special efforts to help a student, like the English teacher in The Perks of Being a Wallflower (Chbosky, 1999), who continually feeds books to the deeply troubled (but voracious reader) Charlie, or Mr. Lema in "The Circuit" (Jiménez, 1993) who gives up his lunch hour to help a 12-year old migrant farm worker with his reading. In The Skin I'm In (Flake, 1998), a teacher with a disfigured face helps a young African American girl, teased all her life because of her dark skin, find the courage to stand up for and take pride in herself. And in The Year of Miss Agnes (Hill, 2000), we see what happens when a teacher encourages her students to pose their own questions, to name their own worlds. Their world, a tiny Athabaskan village restrictive in its remoteness and its established patterns of life, becomes bigger as the children begin to make connections between it and the larger society. "Everything [we did] had something to do with what we had learned from her, as if we just woke up to see the world around us, and way beyond us" (p. 111).

In a number of books, the teacher takes on a more politically active role, challenging school authorities in the interest of the students. After being reprimanded for refusing to do paperwork (including grading his students) until the school provides his class with necessary supplies, the irrepressible Mr. Freeman (note the name) "[finds] a way around the authorities again" (Anderson, 1999, p. 102). Mr. Freeman is naturally combative with the administration, but, in a surprising number of stories, it is the students themselves who inspire the teacher to challenge the powers-that-be. In Whale Talk (Crutcher, 2001), a high school senior persuades his complacent swim coach to challenge the all-powerful wrestling coach over inequities in the athletic awards system. And in The Landry News (Clements, 1999), students actually rekindle the spark in a burnt-out teacher by challenging him to help them resist an increasingly hostile administration seeking to censor their class newspaper.

What might students learn from reading these and other literary works? More than merely demonstrating that curriculum can be meaningful and teachers supportive, the books show that the students themselves can be agents of change in schools. Rather than passively waiting for curriculum and schooling to happen to them, students in the stories_like Dumbledore's Army (Rowling, 2003) — take action to open "revolutionary domains of possibility" (McLaren, 2003, p. 292) for themselves, their teachers, and their communities. Even if the teacher seems unaware of or uninterested in exploring these 
domains of possibility, the students can create them. The literature shows that classrooms and schools can and should be dynamic places.

Greene (1995, pp. 10-11) writes that we need to see things big rather than small.

"When applied to schooling, the vision that sees things big brings us in close contact with details and with particularities that cannot be reduced to statistics or even to the measurable." We see "teachers who provoke learners to pose their own questions, to teach themselves, to go at their own pace, to name their worlds." Our goal in working with students to explore visions of schooling in literature was to help the students to see big-to experience visions of schooling which "awaken others to possibility and the need for action in the name of possibility... [and] communicate the importance of opening spaces in the imagination where persons can reach beyond where they are" (Greene, 1986, p. 430).

\section{Implementing the Curriculum}

Spring River School (a pseudonym, as are all names of places and people in this paper) is a small public middle school located in rural northern California. As in nearly every school in the state and nation, reading and literacy is a primary focus throughout the school curriculum. In fact, the school principal is a former reading specialist who was delighted to have us (a university professor and a school librarian) implement a literature project in her school. The class that participated in our project consisted of 26 fifth and sixth graders who call their teacher Alan by his first name, and who view their overall school experience in generally positive terms. The school environment seems safe both physically and psychologically. In fact, Sylvia, a student who had recently transferred from an alternative school, claimed to feel alienated by this congenial environment. "I like reading books about bad kids because I'm bad and I can't relate to the kids here, because they aren't bad like me," she said. (Of course, this same girl frequently curled up at lunchtime on the bench in the library to read, so "bad" behavior is clearly relative.)

While reading is a major focus at Spring River, curriculum that explores those differences that empower and depower our students is not. Most students, when asked, will tell you that they consider Spring River an "okay" place to go to school. They are accustomed to the teachers' good-natured cajoling to behave and complete their assignments; and teachers can generally count on students' willing, if not always 
cheerful, acquiescence on most curricular and behavioral matters. The politically leftleaning faculty sometimes encourage students to examine national and local political issues; but prior to this project, they had never, as part of the formal curriculum, explored political matters close to home.

Our goal for this project was to explore matters very close to home. As Bigelow (1999) recommends, we wanted students to probe "the invisible life of schools" and to connect their exploration to their own lives. Literature was to be the vehicle for this exploration. Like Pinar (1975, p. 409), we wanted our students to ask the questions, "What do I read and what intellectual or thematic relation exists between the reading and the living? What seem to be characteristic responses to various teachers, to various forms of work (writing, reading, library work), to various types of work (philosophy, history, etc.), and what motives can be inferred? And so on."

With this goal in mind, we collected a broad spectrum of children's and young adult school-related literature (listed at the conclusion of this article), then from that list selected age-appropriate titles to share with the $5^{\text {th }} / 6^{\text {th }}$ grade class. As we read the books in preparation for our first meeting with the students, we developed a system for categorizing the books; we planned to discuss the categories with students to help them understand the range of visions of schooling available in literature. At first, we used Sutherland's (1985) categories of assent, attack, and advocacy; but, the more we read, the more we saw further gradations among the various works of fiction. Eventually, we adapted his categories to create a taxonomy of five types of images of schooling in the books:

1. Acceptance refers to literature that depicts traditional images of schooling, from Anastasia's annoyingly narrow-minded teacher (Lowry, 1979) to Harry Potter's (Rowling, 2003) typical secondary school schedule in the halls of Hogwarts. As with Sutherland's politics of assent, which he characterizes as "an author's passive, unquestioning acceptance and internalization of an established ideology" (Sutherland,1985, p. 151), the dominant ideology of schooling in acceptance literature is invisible: acceptance literature presents the conventions of schooling uncritically.

2. Despair characterizes literature that portrays school as hopelessly oppressive and destructive. As with Sutherland's politics of attack, despair literature portrays examples and events that "that run counter to [the author's] concepts of right and wrong, good and evil, justice, fair play, decency, or truth" (Sutherland, 1985, p. 147); 
but this literature focuses specifically on the brutal impact that schooling can have on too many students. The physical abuse that Roald Dahl (in Boy, 2001) suffers at the hands of older students and his teachers, as well as the ceaseless persecution that Brother Leon inflicts on Jerry Renault in Cormier's The Chocolate War (1974) without any kind of retribution for the oppressors or redemption for the protagonists-epitomize the types of circumstances that characterize literature of despair.

3. Subversion is our term for literature in which teachers or students "fly under the radar" to successfully change their classrooms and/or schools. In Sahara Special (Codell, 2003), rather than making waves in a school whose policies humiliate special needs students, the teacher saves a student from participating in that program by telling a lie (in front of her students) to the special education teacher; similarly, Professor Lupin secretly supports Harry Potter in Harry Potter and the Prisoner of Azkaban (Rowling, 1999), but does nothing to openly challenge the status quo.

4. Resistance literature includes books in which characters successfully confront oppressive teachers, administrators, other students, or school policies. Examples of resistance literature include No More Dead Dogs (Korman, 2000)--where a student defies a teacher who insists he write a complimentary book review about a story the student hated-and Whale Talk (Crutcher, 2001), The Skin I'm In (Flake, 1998), and Standing Up to Mr. O (Mills, 1998).

5. Possibility, our favorite category, encompasses the variety of books that portray whole new conceptions of schooling-visions that we later characterized to students as "outside the box" — such as the home school in Surviving the Applewhites (Tolan, 2002), and the little one-room schools in both The Year of Miss Agnes (Hill, 2000) and The Wheel on the School (DeJong, 1954). We had a harder time finding books in this category than in any other.

We introduced the project to the class by asking students what books they could think of that took place, for at least part of the story, in a school setting. Of course, the first books students named were from the Harry Potter series; from there, their suggestions ranged from old favorites such as the Ramona and Laura Ingalls Wilder books to contemporary titles like Flying Solo (Fletcher, 1998), Maniac Magee (Spinelli, 1990), and The Secret School (Avi, 2003). Then we asked, “When considering all the juvenile books 
you have read in which school appears, what is the most common vision or image of schooling these books present?" After a wide-ranging discussion, we read aloud excerpts from several books that exemplify various categories in our taxonomy, countering fiction that explores and confirms students' negative experiences in school, such as No More Dead Dogs (Korman, 2000) and Matilda (1988), with selections from books that offer examples of curriculum that empowers students and teachers, such as Sahara Special (Codell, 2003). Students then selected books from our collection of fiction offering these multiple viewpoints of schooling, with instructions to read as many of them as possible and to comment on the books in their journals in the coming month.

Over the next three weeks, we met with the class once per week for 40 minutes to discuss the books, alternating class discussions with small group dialogues and in-class writing assignments. At our first small-group meeting, each student described what book he or she was reading and what image of schooling it offered. The next week, we asked them to compare their own experiences with those they were reading about in the literature; then, to help students realize the variety of perspectives among all the books the class was sampling, we introduced our taxonomy and asked them to classify their books according to our categories. And in the final session with the class, we asked students to write what they did or didn't like about the visions of schooling their books presented, in particular what they found to be fair and unfair, and what they could do to change the situation.

At the end of the month, we collaborated with Alan on a culminating multimedia project to create a model school, which would include such characteristics as educational philosophy, curriculum, teacher attributes, school and classroom rules, and physical layout. Our goal was to help students synthesize what they had read and discussed with what they had experienced in the past and could envision for the future. Alan suggested to them that ultimately they might be able to present a composite model school to the principal and the school board. Because the school district is in the midst of consolidating its K-4 school with its 5-8 middle school, this assignment provided the perfect opportunity for the students to take what they had learned from their reading, writing, and thinking - their "wonderings and wanderings" (DeJong, 1954)--over the past month and make that connection between the reading and the living by developing models that would help them envision and, perhaps, create new possibilities for their lives in school. 


\section{Student Responses to the Literature}

From the very beginning, the students were excited about this project. They couldn't wait to start reading; and throughout the project, as they finished their books, they were constantly asking for more books to read from our collection, and sharing those they had read with their classmates. A book that started out with one child might get passed around to three or four others before making its way back to the collection. Some students read as many as five books during the month that we worked with them. Clearly, thinking and reading about schooling was important to them. As our discussions progressed, their thoughts about those books also evolved. In particular, two issues-what different sorts of learning takes place in school, and what is fair and just in school-held great meaning for them, because they returned to these issues again and again.

At first, when we asked what was the most common vision or image of schooling they found in the literature, their responses were predictable: in the literature they remembered, school was "boring" and a "waste of time"; the plot was rarely about a teacher, but teachers were "plodding" ; and there was "usually a bully involved." For these students, school in children's literature was simply background—or as Jennifer put it, "a way into the story." Schooling itself was not the story, and the patterns of a conventional school day presented in these works of fiction-bells ringing, classes changing, teachers lecturing, administrators whose purpose is strictly disciplinary or bureaucratic-were simply an accepted, uncontested part of young people's daily lives.

The vision of schooling that the students at first saw in the literature mirrored their own educational experiences. Almost every student in the class had read the Harry Potter series, so we asked them to compare their schooling with Hogwarts, the boarding school that Harry attends throughout the series. Mostly, the differences they listed were superficial: Hogwarts students live at school, they get to have pets. And although Hogwarts students study such intriguing-sounding subjects as transfigurations and potions, they still have lectures and exams and grades—as José said, "just like regular school." And just like regular school, some teachers are better or nicer than others. Yes, Snape treats Harry unfairly, but the students agreed that, both in books and in the real world, there's a Snape in every school: that's just the way school is. The students argued that both in fiction and in reality what is important in life happens outside of school. As 
Mary wrote about her book, "School is more of a background, an easy setting for the more complicated events occurring outside it. ...I think that this is a generally accurate portrayal of most schools, for the times you remember in the best detail are the ones where you aren't in the classroom."

But as they continued to read and converse about the stories, they began to realize that a book which might not seem to be about schooling actually is when you look "below the surface," and that much of what happens in those school settings directly affects the students' lives outside the classroom as well. For example, Rose noted how the art teacher in Speak (Anderson, 1999) gets the main character "to speak her thoughts through art," which eventually allows her to begin to recover from the trauma she experienced the previous summer. Two weeks into the project, students' journal entries clearly indicated that they were starting to see that the images of schooling in their books played a more important role than they once might have thought. In fact, in Harry Potter and the Order of the Phoenix (Rowling, 2003), schooling is, in Antonio's words, "the main point" of the whole story. Once the students realized that the fifth Harry Potter book was all about the struggle for control of knowledge and information, they began to point out power relations in other books, such as Anastasia Krupnik (Lowry, 1979). In discussing Anastasia's encounter with her teacher who insisted that poetry had to rhyme, Doug commented, "If a teacher only tells you what he thinks about things, you wouldn't really be learning what you need to know."

In their discussions about the books, the students began to consider how much meaningful learning can actually take place in school-learning that may have nothing to do with spelling, math skills, or even transfiguration and defense against the dark arts, but which might involve knowledge that is far more long-lasting and important to them than the specific subjects usually associated with schooling. Some of this knowledge might be unpleasant or unsettling, but what students learn, they realized, also could be transformative. As Kevin wrote about Flying Solo (Fletcher, 1998), in which the students decide to run their own class by not informing the administration when the substitute teacher doesn't show up:

My feeling of this book is that it is trying to show that kids can take care of themselves, and the characters in this book are having a very enlightening experience. The kids begin to learn who their friends and classmates really were. 
The kids also learn that there are situations where adults can be very handy but sometimes can't understand everything that happens to children.

Kevin recognized that the "struggle for meaning and a struggle over power relations" taking place in his book is about more than just life in this classroom, that it epitomizes adult/child struggles that take place in every part of his life. In focusing on these school stories, students began to see that school is a place where students can and should examine, evaluate, and try to make sense of their lives.

Almost every discussion came around in some way to what was being taught, how it was being taught, and what was important to learn in school. They liked the way the teacher in The Year of Miss Agnes (Hill, 2000) taught the class about Italy, for instance, by playing opera records. "School should be interactive," said Serena. And Benjamin added, "We should learn practical things in school, like woodworking." In considering all the Harry Potter books, students noted that, while structurally the schooling at Hogwarts was similar to their own school, Hogwarts was far superior because its curriculum was "much more interesting." As Jeremy argued, "They get to do experiments and we just sit at desks and learn." Rose commented wistfully that at Hogwarts, "There is danger involved in learning." Even detention can be a learning experience: José objected to the way students had to sit during detention in No More Dead Dogs (Korman, 2000), arguing that the students would learn more from "picking up trash." For all of the students, experiential learning that is of interest and / or of use to them, even if it results in getting sent to the hospital or picking up trash, offered a more desirable alternative to the daily learning experiences to which they are accustomed.

After the students had read at least two books each, we wrote the five different categories of our taxonomy on the whiteboard and asked where they would fit the books they had read. Student responses again revealed that they were becoming more critical readers and, in fact, that their evolving interpretation of the literature was quite different from what we had expected. They surprised us, for example, in their analysis of

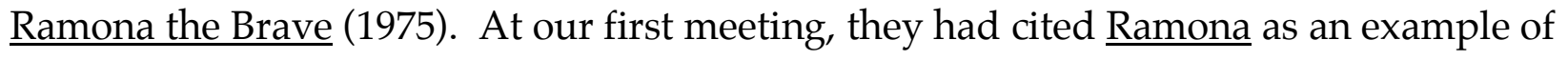
a book in which school is just insignificant background to the real story. Like us, they had seen it as an example of acceptance literature that reifies the status quo. But in discussing where to fit it into our taxonomy, they argued for placing it in the fourth category, because, they argued, Ramona is a character who continually resists the status quo. They cited her refusal to write the $Q$ in her name the way her teacher insists she do, 
and her crumpling up of another child's paper who has copied her work. But because she is punished for both offenses, they decided the book belonged with the literature of despair. Using the taxonomy as a guide, they realized not only that there are multiple interpretations of a work of literature, but also that their original interpretation of schooling in the Beverly Cleary books---that that's just the way school is-was in fact Cleary's challenge, even condemnation, of that very reality. As part of the process of becoming more critical readers, they were coming to see that many of the books that they had originally grouped with the literature of acceptance perhaps deserved a second look, and that schooling and their interpretations of daily experiences in school were considerably more complex than they had originally imagined.

Perhaps the most memorable example of students' evolving understanding of the literature and of schooling itself is the ongoing conversation about social justice that the books stimulated. From the very beginning, students noted the tendency of school stories to feature bullies. Anna, in writing about Hoot (Hiaasen, 2002), stated, "School is like an ordinary school. The kid doesn't like school because he is constantly being bullied. School gets worse and worse. He accepted things as they are but hates them anyway." To our students, "ordinary school"- - both in fiction and in their own lived experience--features school authorities who not only ignore bullying, but sometimes even penalize the student being harassed instead of the bully.

This response to the literature surprised us. As mentioned above, from our vantage point, the students seemed to feel safe and well cared for both in and outside the classrooms at Spring River School. Yet our students' acceptance of the harassment and intimidation that takes place in the stories as "normal" —and their general agreement that these dynamics are universal in schools_-indicated that they are a part of daily life even for Spring River students. In fact, Mary expressed concern about the lack of adult awareness of power struggles among students when she wrote about Stargirl (Spinelli, 2000), "I don't like the way teachers weren't aware of what was going on around them." She also lamented that the main character "could have told his parents about the problem if they were there. But they weren't even in the story!" Because Mary herself has a strong family support system, she could not understand why parents played no part in the lives of the characters in Stargirl. But at least now, with the literature providing a starting point, the students had found a forum in the classroom for discussing such issues. 
Anastasia Krupnik (Lowry, 1979) provided another opportunity for students to discuss their concerns about fairness and social relations in the classroom. Anastasia's school is another one of those "ordinary" schools which the class at first dismissed as mere background to the real action. On our first day with the class, after we read aloud the excerpt in which Anastasia's teacher publicly fails her for not rhyming her poem, the class was absolutely silent for a minute, momentarily stunned by the teacher's unfairness. Yet when we asked for their reactions, students had little to say. A couple of weeks later, however, after we had introduced our five categories of schooling literature and they had discussed various books which offer possible responses to such injustices, they returned to this scene and discussed the ways Anastasia (who passively accepts the teacher's evaluation) could have responded:

"She could resist by causing trouble."

"Or do it under the radar, like Harry and Hermione."

"She could have lost her temper and exploded like Ramona does."

"She could fight back, like Harry Potter does, casting spells."

"But a spell against a teacher in Hogwarts could get you killed."

"He still does spells, even when they are dangerous."

"Anastasia should have stood up for herself no matter what, just like Harry does."

These and other such discussions showed us that student reflection on the literature and their relationship to it had evolved considerably in the few weeks we worked with them. In the first place, their discourse was different: words and phrases like "resist" and "under the radar," which had come from our taxonomy, provided a common language with which to describe the situations and possible responses to injustice in school. According to Gee (1996), the way we use language is both constituted by and constitutive of the context in which it occurs; that is, language in use not only represents perspectives, but creates them as well. Thus, our considerations of acceptance, despair, subversion, resistance, and possibility in the world views presented in the literature helped students to envision new ways of being in the world.

Critiquing the actions of characters in the stories served as a starting place for students' conversations, which gradually began to extend beyond the literature and into their own worlds. In the discussion of Anastasia's humiliation, their focus shifted from the events in the story to what they themselves would do in similar circumstances: 
"I would say to the teacher, look up poetry: there are lots of other ways of looking at things."

"You can tell the teacher that it hurt your feelings and wasn't right to grade in public."

I would stand up to the teacher and say she was unfair ." Harste (2004) argues that the kind of social practice that reading becomes is directly related to what discourses are made available to them. By asking them to write about what was fair and unfair in the books, and what they would do to change the situations, we made available to the students an opportunity to explore a topic that was important to them, but which they had previously considered outside the realm of legitimate school knowledge. Here is a sampling from their final written assignment:

"I would change how Fudge gets his way in every situation." (Double Fudge [Blume, 2002])

"I would make it so there was another bully to pick on Bastion to make him change." (Flying Solo [Fletcher, 1998])

"I would have Tim come back to the school and have Stacie's dad arrested." (Friction [Frank, 2003])

"I would bring it to the attention of the faculty that some students were being ignored because they were different." (Stargirl [Spinelli, 2000]) Greene (1995, p. 48) writes, "There are no specific blueprints for a better society or even a better school system. But we might well begin to shape our imagining by exploring more images from literature." The literature of subversion, resistance, and possibility provided virtually unlimited images from which to choose, images which demonstrated to the students that they, like the characters in the stories, had the creativity, the resourcefulness, and the right to counteract cruelty, injustice, or, even, uninspiring teaching. We moved from the reading phase of this project into the culminating activity with the hope that students would shape their imaginings into something solid and concrete: their model schools.

\section{Applying the Readings: Students' Model Schools}

The two themes of curriculum and social justice, which dominated student response to the literature, also provided the basis for almost every group's model school. 
When we had read excerpts from different books to the class on the first day of our project, students had laughed aloud when they heard the daily schedule that Miss Pointy, the teacher in Sahara Special (Codell, 2003), writes on the board: Puzzling, Time Travel and World Exploring or Mad Science, Read Aloud after Lunch, Read Together after Read Aloud, Read Alone after Read Together, and Art of Language. At the time, it had seemed silly to them, contrary to the daily school schedules to which they were accustomed. But by the end of the project, when the time came to design their own, model schools, the students demonstrated that they had moved from laughing at to embracing alternative, albeit imaginary visions of curriculum. The subjects they chose for their curricula mirrored the free spirit of Miss Pointy's schedule: Doodling, Field Trips, More Walks Outside, P.E. Every Day, Reading (“spread out over a longer time!”), Art Every Day, Foreign Languages, Cooking, Tournaments, and Electronics. At the same time, all groups deliberately sought equality in their school programs: most required "leveled" math classes so students could work at their own pace; most eliminated the gifted and talented pull-out program, because, they explained, it wasn't fair that the "smart" kids got to do special, usually more interactive, projects; and they all listed among their values "treating each other with respect." Even the subject of "Future Telling" was an egalitarian one:

In this class kids learn to tell the future with tea leaves and dreams. It will allow you to study for a test before the teacher announces it, but it will not help you into getting a better grade than you are capable of.

With their focus on alternative courses of study and concern for social justice, students' model schools reflected the considerable impact that the literature had had on their visions of schooling. But at the same time, the structures of their schools varied little, if at all, from the familiar. Students placed those alternative courses of study into frameworks identical to their own daily schedules, with period after period governed by the ever-present clock. Several groups worked out intricate schedules to the nearest minute (i.e. "First Period 7:35 - 8: 27, Second Period 8:29 - 9:21," and so on), allowing students in their schools a mere two or three minutes to travel between classes.

Knowledge, in their minds, still fit into discrete categories, each discipline consisting of a series of particular facts and skills to master. The daily schedules offered some slight variations on the norm-alternative day schedules, "college schedules," built-in field trip 
days-but few of the model schools offered the learners any control over what they would learn or when they would learn it. Visions of student-driven inquiry, illuminated in books like The Wheel on the School (DeJong, 1954) and Regarding the Fountain (Klise, 1998), were either forgotten or discarded. When we suggested that students consider alternative structures, Benjamin responded, "There's nothing wrong with the schedule we have. If you're getting really tired of what you're studying, you only have it for a little while!"

We found still more adherence to traditional schooling in the long lists of rules that students created for their model schools. To be sure, some of the rules-such as "not as much cussing," "no fighting," "no dress code," and "eating in class permitted"reflected their concerns about bullying and fairness. But most of the rules were little different from the rules in most public schools: "No drugs, cigarettes, or alcohol," "no obscene clothing or language," and "no unsupervised climbing" (actually, we have no idea where that last rule came from). The notion of a classroom environment in which the rules might evolve out of community consensus (such as in Flying Solo [Fletcher, 1998]) was never even considered. Almost everyone had been noticeably impressed by the visions of possibility in books like Surviving the Applewhites (Tolan, 2002) “Awesome school!" gushed Sylvia_-and Regarding the Fountain (Klise, 1998)__I liked how free the teacher let [the students] be," wrote Katie-but their model schools showed that they were not yet ready to take those visions and translate them into reality.

\section{Conclusion: Envisioning Possibility}

According to Eisner (1998, p. 19), when writers' skills are great, "they give us material that helps us understand, paradoxically, what words cannot express." Scholars and teachers often champion literature as a tool for teaching in particular content areas, but rarely do they recognize its potential for "seeing big"_for reconceptualizing what Apple (1975, p. 113) calls "the commonsense reality in which students and teachers dwell." Literature can serve as a catalyst for the classroom community, as Osborne and Barton (1998, p. 255) advocate, "to build connections between the theoretical construct of liberatory education and the lives of teachers and students."

The zeal with which students at Spring River School read and thought and talked about the literature of schooling demonstrated their deep and abiding interest in exploring this commonsense reality; but the model schools they developed bore less 
resemblance than we would have liked to the literature of possibility they had read or to their insightful responses to these books. Because their visions for model school environments, if feasible, could possibly have been incorporated into the reconfigured Spring River School the following year, the culminating activity could have provided the perfect opportunity for the students to become true agents of change in their community; yet they chose instead to create entertaining but somewhat trivial and largely

unrealizable plans. In fact, when we asked students whether the readings had influenced their decisions for curriculum and school design, most students replied, "Not really." Mary, one of the most articulate and insightful in the class, told us, "Most of my ideas just came from my imagination."

Why did student projects fail to break "outside the box?" One logical explanation might be that this unit was, for most of the students, the first time that they had been invited to explore and develop new ideas about what Apple (1975, p. 113) calls "the paradigms of activity within their everyday lives at school." How could we expect one month (40 minutes per week) of conversations to significantly alter the students' conceptions of a system in which they had spent 180 days per year for the previous five to seven years? Lortie (1975) uses the phrase "apprenticeship of observation" to refer to the way people learn to teach by watching their teachers over the course of their K-12 experience, and this phrase could just as easily apply to the way students learn about their position and role in schools. Certainly, ongoing critical examination of curriculum and schooling throughout students' school careers-using not only literature, but film, music, television, art, and scholarly writings_-would enhance students' awareness and understanding of the issues that we introduced at Spring River School.

Still, Mary's assertions notwithstanding, we found some compelling evidence suggesting that the literature and the conversations we engaged in for one short month may have induced a shift, however subtle, in students' perceptions of schooling. For example, the centerpiece of one of the model schools was a beautiful fountain. It so happens that one of its designers had read Regarding the Fountain (Klise, 1998), in which a class battles with administrative bureaucracy and corruption to get a drinking fountain at its school. Then there was Keanu, a quiet, thoughtful child, who had read several of the books from our collection, and pointed out that all those books had amenities that Spring River didn't have, like auditoriums and cafeterias and music rooms. His model school had a huge auditorium right in the center. And perhaps some 
of those clever but entirely infeasible course offerings might in fact have been calls for true and meaningful alternatives to curriculum-as-usual. Sandwiched in between such curricular staples as "Textbooks," "Lunch is one hour," and "Pajama Day," we found plans like "Choose some of your periods" and "Different levels of testing and teaching."

Anybody who spends time with children and young adults either inside or outside the classroom hears frequent talk about their schooling, and much of what we hear often involves complaints, suggestions, and the same cries of unfairness that came up in our discussions with Spring River students. But these issues usually hover around the margins of school life, outside the realm of sanctioned school conversation. It was our goal to bring these issues into the realm of legitimate classroom discourse. Harste (2003, p. 9) writes that classroom discussions of books should involve "opening up spaces in the curriculum for starting some much needed new conversations" about social practices which encourage students to ask "What is being taken for granted and what other ways are there to think about this thing being discussed?" In their examination of schooling, the fifth and sixth graders asked these kinds of questions and, in the end, they provided some tentative answers for themselves. One group's description of its model history class shows just how powerfully a vision of possibility can leave its mark:

In this class, we do not only teach the students the regular history as known in other schools, we also make the students think of ideas to change the world. Instead of just learning useless facts, we want them to extend their knowledge and think out of the box and into the real world. Such a vision of schooling is neither trivial nor unrealizable. It is a vision that provides meaning and challenge to those who believe in it, and it is well worth striving for. 


\section{References}

Apple, Michael, "The hidden curriculum and the nature of conflict," in $\underline{\text { Curriculum }}$ Theorizing: The Reconceptualists, William Pinar, ed., pp. 95-119. Berkeley: McCutchan, 1975

Apple, Michael, Cultural Politics and Education. New York: Teachers College Press, 1996.

Bigelow, Bill, "Probing the invisible life of schools," in Making Justice our Project, Carole Edelsky, ed, pp. 242-257. Urbana, IL: NCTE, 1999.

Block, Alan, I'm Only Bleeding: Education as the Practice of Violence against Children. New York: Peter Lang, 1997.

Britzman, Deborah, "Cultural myths in the making of a teacher: Biography and social structure in teacher education," Harvard Educational Review, 1986, 56(4), 442-456,

Eisner, Elliot, The Enlightened Eye: Qualitative Inquiry and the Enhancement of Educational Practice. Upper Saddle River, NJ: Merrill, 1998.

Everhart, Robert, Reading, Writing, and Resistance. London: Routledge and Kegan Paul, 1983.

Freire, Paolo, Pedagogy of the Oppressed, translated by Myra Bergman Ramos. New York: Continuum, 1990.

Gee, James, $\underline{\text { Social Linguistics and Literacies: Ideology in Discourses, }} 2^{\text {nd }}$ edition. Bristol, PA: Falmer Press, 1996.

Giroux, Henry, Teachers as Intellectuals: Toward a Critical Pedagogy of Learning. Granby, MA: Bergin \& Garvey, 1998. 
Giroux, Henry, \& McLaren, Peter, "Teacher education and the politics of engagement: The case for democratic schooling" Harvard Educational Review, 1986, 56(3), 213-238.

Goodman, Jesse, Elementary Schooling for Critical Democracy. Albany, NY: SUNY Press, 1992.

Gough, Noel, "Reflections and diffractions: Functions of fiction in curriculum inquiry," in Curriculum: Toward New Identities, William Pinar, ed., pp. 93-128. New York: Garland Publishing. 1998.

Greene, Maxine, "Curriculum and consciousness" in Curriculum Theorizing: The Reconceptualists, William Pinar, ed., pp. 299-317. Berkeley: McCutchan, 1975.

Greene, Maxine, "In search of a critical pedagogy," Harvard Educational Review_, 1986, 56(4), 427-441.

Greene, Maxine, Releasing the Imagination: Essays on Education, the Arts, and Social Change. San Francisco: Jossey-Bass, 1995.

Harste, Jerome, "What do we mean by literacy now?" Voices from the Middle, 2003, 10(3), 8-12.

Harste, Jerome, Literacy: Making our Classroom Critical, presented at Mary Collins School Symposium, Petaluma, CA, March 6, 2004

Heilman, Elizabeth, "Blue wizards and pink witches: Representations of gender identity and power," in Harry Potter's World: Multidisciplinary Critical Perspectives, Elizabeth Heilman, ed., pp. 221-240. New York: RoutledgeFalmer, 2003.

Hirsch, E.D., The Schools We Need, and Why We Don't Have Them. New York: Doubleday, 1996. 
Kliebard, Herbert, Forging the American Curriculum: Essays in Curriculum History and Theory. New York: Routledge, 1992.

Kohl, Herbert, "I won't learn from you" and other thoughts on creative maladjustment. New York: New Press, 1995.

Lortie, Dan, $\underline{\text { Schoolteacher. }}$ Chicago: University of Chicago Press, 1977.

McLaren, Peter, Life in Schools: An Introduction to Critical Pedagogy in the Foundations of Education, $4^{\text {th }}$ ed. Boston: Allyn and Bacon, 2003.

Nilsen, Alleen Pace, \& Donelson, Kenneth, Literature for Today's Young Adults, $4^{\text {th }}$ ed. New York: HarperCollins, 1993.

Osborne, Margery, \& Barton, Angela Calabrese, “This issue: Constructing a liberatory practice in school subjects," Theory Into Practice, 1998, 37(4), 254-255.

Pinar, William, "Currere: Toward reconceptualization," in Curriculum Theorizing: The Reconceptualists, William Pinar, ed., pp. 396-414. Berkeley: McCutchan, 1975.

Pinar, William, "Preface," in Toward a Poor Curriculum, William Pinar \& Madeleine Grumet, eds., pp. vii-x. Dubuque, Iowa: Kendall/Hunt, 1976.

Sutherland, Robert, "Hidden persuaders: Political ideologies in literature for children," Children's Literature in Education, 1985, 16(3), 143-157. 


\section{Selected Children's and Young Adult Fiction}

Almond, David, Skellig. New York: Delacorte, 1998.

Anderson, Laurie Halse, Speak. New York: Puffin, 1999.

Arter, Jim, Gruel and Unusual Punishment. New York: Delacorte, 1991.

Avi, Nothing but the Truth. New York: Avon, 1991.

Avi, The Secret School. New York: Harcourt, 2003.

Bloor, Edward, Tangerine. New York: Scholastic, 1997.

Byalick, Marcia, Quit It. New York: Random House, 2002

Blume, Judy, Double Fudge. New York: Dutton, 2002.

Chbosky, Stephen, The Perks of Being a Wallflower. New York: Pocket Books, 1999.

Clavell, James, The Children's Story. New York: Dell, 1989.

Cleary, Beverly, Ramona the Brave. New York: William Morrow, 1975.

Cleary, Beverly, Dear Mr. Henshaw. New York: Dell, 1983.

Clements, Andrew, Frindle. New York: Simon \& Schuster, 1996.

Clements, Andrew, The Landry News. New York: Simon \& Schuster. 1999.

Clements, Andrew, The School Story. New York: Simon \& Schuster, 2001. 
Codell, Esme Raji, Sahara Special. New York: Hyperion, 2003.

Cormier, Robert, The Chocolate War. New York; Pantheon, 1974.

Creech, Sharon, Bloomability. New York: Scholastic, 1998.

Creech, Sharon, Love That Dog. New York: Harper Collins, 2001.

Crutcher, Chris, Whale Talk. New York: Greenwillow, 2001.

Dahl, Roald, Matilda. New York: Viking Kestrel, 1988.

Dahl, Roald, Boy: Tales of Childhood. New York: Puffinm 2001.

DeJong. Meindert, The Wheel on the School. New York: Harper \& Row, 1954.

English, Karen, Francie. New York: Sunburst, 2002.

Flake, Sharon, The Skin I'm In. New York: Hyperion, 1998.

Fletcher, Ralph, Flying Solo. New York: Clarion, 1998.

Frank, E.R., Friction. New York: Atheneum, 2003.

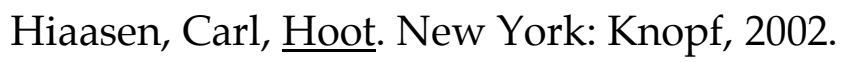

Hill, Kirkpatrick, The Year of Miss Agnes. New York: Aladdin, 2000.

Howe, James, The Misfits. New York: Atheneum, 2001.

Jiménez, Francisco, "The circuit," in America Street: A Multicultural Anthology of Stories, Anne Mazer, ed, pp. 23-31. New York: Persea, 1993. 
Juby, Susan. (2003). Alice, I Think. New York: Harper Tempest.

Klise, Kate, Regarding the Fountain: A Tale, in Letters, of Liars and Leaks. New York: Avon, 1998.

Konigsburg, E.L., The View from Saturday. New York: Atheneum, 1996.

Korman, Gordon, No More Dead Dogs. New York: Hyperion, 2000.

Lowry, Lois, Anastasia Krupnik. New York: Houghton Mifflin, 1979.

McNamee, Graham, Sparks. New York: Wendy Lamb, 2002..

Mills, Claudia, Standing Up to Mr. O. New York: Farrar, Straus, \& Giroux, 1998.

Nelson, Blake, The New Rules of High School. New York: Viking, 2003.

Oates, Joyce Carol, Big Mouth and Ugly Girl. New York: Harper Collins, 2002.

Rowling, J.K., Harry Potter and the Prisoner of Azkaban. New York: Scholastic, 1999.

Rowling, J.K., Harry Potter and the Order of the Phoenix. New York: Scholastic, 2003.

Sacher, Louis, Wayside School is Falling Down. New York: Lothrop, Lee, \& Shephard, 1999.

Snicket, Lemony, The Austere Academy. New York: Harper, 2000.

Skinner, David, The Wrecker. Simon Pulse, 1997.

Spinelli, Jerry, Stargirl. New York: Knopf, 2000.

Spinelli, Jerry, Maniac Magee. Boston: Little, Brown, 1990. 
Tolan, Stephanie, Surviving the Applewhites. New York: HarperCollins, 2002.

Van Draanen, Wendelin, Flipped. New York: Knopf, 2001.

Voigt, Cynthia, Dicey's Song. New York: Atheneum, 1982.

Voigt, Cynthia, It's Not Easy Being Bad. New York: Atheneum, 2000.

Wilder, Laura Ingalls, These Happy Golden Years. New York: Harper, 1953.

Yolen, Jane, Wizard's Hall. New York: Scholastic, 1991. 